\title{
THE IMPACT OF EXPLORATION ON RESOURCE UTILIZATION AND GOAL FOCUS IN TELECOMMUNICATION INDUSTRY
}

\author{
${ }^{1}$ Oloda Oluwatayo Felix $\&^{2}$ DR. A.D. Alagah \\ 1,2, Department of Management University of Port Harcourt
}

\begin{abstract}
This research investigated the relationship between Organizational exploration, resource utilization and goal focus in Nigerian Telecommunication firms. The sample for this study consisted of 84 management staff from the four leading Telecommunication giants (MTN, Globacom, Airtel and 9 Mobile). The data for this research was collected using the questionnaire method. The Kendall Tau statistical tool was used to test the relationships between the variables under review. The findings reveal a significant positive relationship between Exploration and both of Resource utilization and Goal focus. It was concluded based on our statistical analysis that organizational exploration enhances corporate health. More specifically, it was concluded that exploration enhances resource utilization and goal focus. In view of these results and conclusions above, this study recommends that; Managers should acknowledge the importance of exploration in fostering a better resource utilization which will bring about a healthy organization. Employee involvement, especially employees that are opened to change should be encouraged at all organization level.
\end{abstract}

Keywords: Exploration, Resource utilization, goal focus, health, organization 


\section{Introduction}

The health status of an organization especially in a challenging environment is characterized by high levels of uncertainty and intense competition occasioned by globalization and rapid technological advancement will be a long way in predicting the future of such organization. In order to survive and excel in the middle of a retinue of complexities especially from the external environment with dare consequences and characteristics beyond direct influence of management there is therefore the need to imbibe and sustain capacity to innovate so also the ability to incrementally and successfully shift to fresh opportunities (Heifetz and Linsky 2002). A healthy organization is a wealthy organization, and if the goal of organizations among other goals is to maximize the wealth of its stock holders, then it becomes imperative that the organization strive towards good health, this is so because if an organization is unhealthy (ill) the realization of its strategic objectives becomes a mirage.

Initiating an ambidextrous strategy in an organization could immunize the organization against imminent and possible illness; as such initiatives could give room for cost effectiveness as well as making firms to sustain different customers' needs which is most desirable. Moreover, ambidexterity is vital for organizational health and survival as well as its success.

Previous studies points to the fact that many firms that exhibits healthy traits by way of being very successful are known to be ambidextrous. According to Benner and Tushman, (2003), many ambidextrous organizations possess the ability and the capacity to create a competitive advantage via the advancement of exploitative and exploratory innovation simultaneously. Ambidextrous organizations achieve the coordination of their current operations while simultaneously effectively adapting to changing environmental demands (Gibson and Birkinshaw, 2004; Jansen, 2005; Raisch and Birkinshaw, 2008).

Broadly speaking ambidexterity connotes organization's ability to pursue two different things at one go. Ambidextrous firms have the capacity to exploit prevailing competencies together with exploring new opportunities with same dexterity.

Ability to pursue at the same time explorative (radical) as well as exploitative (incremental) innovation simultaneously so as to remain competitive in the long-run is a major challenge for organizations (March, 1991). Scholars have come to the general agreement that ambidextrous firms are those who possess the capacity to exploit prevailing competencies and explore new opportunities. Irrespective of these general consensus, there is considerable ambiguity and some vagueness regarding the nature of exploitation and exploration and vice versa ambidexterity construct (Cao, Gedajlovic and Zhang, 2009; Junni, Sarala, Taras and Tarba, 2013; O'Reilly and Tushman 2013). A major argument in respect of organizational ambidexterity research points to the fact that firms either connected or balanced ambidexterity are more likely to achieve better performance effects when compared to those who lay much emphases on one activity over the other (Junni et al., 2013; Raisch and Birkinshaw, 2008).

Ambidextrous organizations can easily achieve success in an atmosphere characterized by high degree of turbulence (Gibson and Birkinshaw, 2004).

The idea that heralds the value of Organizational' Ambidexterity is that in an organization there are always tensions to be faced (e.g., investment in current and future projects, 
differentiation vs. low-cost production). Ambidextrous companies coordinate them and in so doing they become successful companies (Gibson \& Birkinshaw, 2004). Ambidexterity compels managers to reason paradoxically. In real sense, ambidexterity concept goes far beyond the mere reconciliation between two tensions. Usually paradoxically ambidextrous approaches manage to get both poles at a high level.

However, several empirical studies have in the past established a connection between other organizational results and organizational ambidexterity, but no empirical evidence has been created on corporate ambidexterity and corporate health, especially in the Nigerian work environment in general and in the work environment telecommunications sector. For example, Hernández, Sánchez-Pérez and Segovia-López (2011), concludes that both exploitation and exploration proved to positively affect organizational performance. Thus, a firm that engages in both exploitation and exploration activities enjoys a great level of organizational performance. Some researchers have argued that exploration and exploitation are mutually exclusive; an indication that the connection between exploitation and exploration is negative, conversely, Gupta, Smith, and Shalley (2006) opined that this is not necessarily true and that the link between exploration and exploitation may be positive. Given the fact that past studies on the organizational ambidexterity concept are yet to establish any relationship with corporate health irrespective of empirical evidence of positive and significant link between ambidexterity and other organizational results makes this study imperative.

$\mathbf{H O}_{1}$ : There is no significant relationship between exploration and resource utilization in the Nigerian telecommunication sector

$\mathbf{H O}_{2}$ : There is no significant relationship between exploration and goal focus in the Nigerian telecommunication sector

\section{Theoretical Framework}

\section{Organizational Learning Theory $(\mathrm{OL})$}

Though there is no universal theory of OL (Easterby Smith, 1997), the general OL schema includes a learner, a learning process, and a learning product (Argyris \& Shon, 1996). But March (1991) propounded a model of organizational learning where he discussed the complementary nature of learning.

\section{The Learner}

Researchers have discussed this schema by focusing on one or all of the three elements. Some scholars believe the individual is the learner (Holmqvist, 2009). Others believe the organization is the learner (Dixon, 1992). Researchers believe it is not easy to discern whether it is the individual learner who learns in an organization or whether it is the organization itself (Gioia\& Sims, 1986).

Many believe OL is likely to remain an umbrella 'concept for many related concepts (Argote, 1999).Concepts relevant to the individual as learner include cognition (processes of knowing), and the information processing model, where individuals acquire, form, store, manipulate, and discard information (Akgun et al., 2003). Other concepts point to the organization as learner. One is the concept of absorption capacity, 'which refers to the 
organization's learning ability. Organizations with high absorptive capacity are able imitate or adapt the innovations of others to their own needs, and are also able to create and exploit new knowledge (Cohen \&Levinthal, 1989).

The immensity of absorptive capacity translates to high levels of Exploitation and Exploration and subsequent Organizational Ambidexterity. But organizations vary in the levels of absorptive capacities and/or learning abilities they possess (Argote, 1999; Katila\& Ahuja, 2002). This variation is the disparity between discovering 'organizations and enacting 'organizations (Brown \& Duguid, 1991). Discovering organizations possess a reactive stance and adapt efficiently and logically to environmental changes. Conversely, enacting organizations proactively create the transformation in the environment they would be interested in seeing, and then respond to them.

In this conceptual framework, discovering organizations possess high exploitative competence whereas enacting organizations are highly explorative.

Marquardt (1999) describes the difference between organizational learning and individual as follows:

Organizational Learning occurs through the shared insights, knowledge, and mental models of members of the organization. Second, it relies on past experience and knowledge that is, on organizational memory, which based on institutional mechanisms (e.g. strategies, policies and explicit models) employed in retaining knowledge. Third, Organizational Learning represents the enhanced intellectual and productive capability gained through corporate-wide commitment to continuous improvement.

\section{The Learning Process}

Some researchers choose the learning process itself as a central point of Organizational Learning. Organizational Learning is defined by Pisano (1994) as a problem solving process triggered by gaps between actual and potential performance. Organizational Learning is a process that enhances the strategic renewal of an organization (Crossan, Lane, \& White, 1999).

Additionally, Organizational Learning is a process occurring when knowledge about action outcome relationships and the effect of the environment on these relationships is developed. The link between organizations and their environments may be achieved through Organizational Learning, a process of identifying environmental changes and contexts, and successfully coping with them.

\section{The Learning Product}

The learning product of OL is change; the creation of something new. The something new "need not be tangible or observable; it may be related to insights or new understandings (Huber, 1991).

Definition of Organizational Learning is relevant here. He claims that the entity will know if the range of its potential behavior has changed through information processing. The learning product of change implies learning does not only involve learning something new, but unlearning something old that is blocking the way for the new to emerge (Szulanski, 2003). For Weick (1991), the outstanding characteristic of learning is combination of same stimulus 
and different response. Weick (1991) contends individual learning happens when same stimulus and different response is accomplished at the individual level and organizational learning happens when same stimulus and different response is accomplished by groups of persons in the organization. Others believe learning and change occur throughout the firm, at individual, team, and organization levels (Akgun, Lynn, \& Byrne, 2003).

\section{Methodology}

The population of this study consists of all Telecommunication firms registered with the Nigerian Communication Commission (NCC). However, this study only focused on the four major and visible firms that have national coverage namely MTN, Airetel, Globacom and 9 mobile with a population of 190. A sample size of 129 was gotten using Taro Yamene formula. To empirically evaluate the relationships between organizational ambidexterity and corporate health in Nigerian telecommunication firms, data obtained with the aid of questionnaire was analyzed using the Kendall's Tau correlation Coefficient statistical technique. The test requires that the responses be at least ordinal level. That is, the response can be ranked from high to low. This statistical tool is considered appropriate as the variables in this study were measured in ordinal scales.

\section{Data Analyses}

Table 1. Correlations between exploration, resource utilization and goal focus

\begin{tabular}{|c|c|c|c|c|c|}
\hline & & & Exploration & $\begin{array}{l}\text { Resource } \\
\text { Utilisation }\end{array}$ & Goal Focus \\
\hline \multirow{9}{*}{ Kendall's tau_b } & \multirow{3}{*}{ Exploration } & Correlation Coefficient & 1.000 & $.305^{* *}$ & .385 \\
\hline & & Sig. (2-tailed) & & .000 & .000 \\
\hline & & $\mathrm{N}$ & 84 & 84 & 84 \\
\hline & \multirow{3}{*}{$\begin{array}{l}\text { Resource } \\
\text { Utilisation }\end{array}$} & Correlation Coefficient & $.305^{* *}$ & 1.000 & $.491^{* *}$ \\
\hline & & Sig. (2-tailed) & .000 & & .000 \\
\hline & & $\mathrm{N}$ & 84 & 84 & 84 \\
\hline & \multirow{3}{*}{ Goal Focus } & Correlation Coefficient & .385 & $.491^{* *}$ & 1.000 \\
\hline & & Sig. (2-tailed) & .000 & .000 & \\
\hline & & $\mathrm{N}$ & 84 & 84 & 84 \\
\hline
\end{tabular}

**. Correlation is significant at the 0.01 level (2-tailed).

Table 1 revealed the correlations between exploration and resource utilization, and exploration and goal focus. The output showed moderate positive relationships between the variables. Specifically, there was a moderate positive relationship between exploration and resource utilisation (tau_b $=.305, \mathrm{n}=84, \mathrm{P}<.01$ ), while the relationship between exploration and goal focus was also moderately positive (tau_b $=.385, \mathrm{n}=84, \mathrm{P}<.01$ ). These results imply that, the higher the exploration among the firms, the higher the achieve resource utilization and goal focus. Based on these results, the null hypotheses were rejected and the alternative hypotheses accepted.

\section{Discussion of Findings}

The first cluster comprises hypotheses one and two. The results in table 1 above indicate moderate correlations between exploration and both proxies of corporate health (resource 
utilization and goal focus). The relationships were positive and significant enough to reject the null hypotheses (1 and 2).

This result signifies that exploration efforts by the telecommunication firms have a moderate influence on corporate health. More so, higher level of exploration leads to higher level of resource utilization and goal focus since the correlation values were positive. Therefore, the null hypotheses ( 1 and 2 ) were rejected and their alternative accepted.

Thus, it is concluded that:

i. Exploration leads to higher level of resource utilization among the telecommunication firms in the South-South geopolitical zone in Nigeria.

ii. Increase in exploration activities results to increase in goal focus among the telecommunication firms.

\section{Conclusion}

The result shows that exploration has a positive and significant relationship with resource utilization. Although no study in time past have linked ambidexterity with corporate health but this finding can be juxtapose with the findings of Auh and Mengue (2005) who reported a significant relationship between organizational Ambidexterity and firms Growth, we argue here that firm's growth is synonymous to corporate health given the fact that for a firm to grow, her health status must be perfect, an organization can be tagged artificial human. The biological being must be in good health in other to grow, otherwise the growth will be distorted, this can also be liken to organizations, it is on this premise we hinged our argument that this finding is similar to the findings of Auh and Mengue (2005). This means that exploration positively influence resource utilization. That is when an organization has the capacity to explore existing competencies such organization will achieve a perfect health status. Most organizations lack the ability to effectively and efficiently coordinate and maintain inputs; particularly personnel with a minimal sense of strain. It is important that firms offers insights for practitioners on how they can build up their internal resources as organizational capital, over which they have relatively greater control than external factors, to enhance the corporate health.

Ambidexterity propels organizations and their employees to go beyond boundaries in their task description, fostering inter-employee support and trust. Furthermore, these employees are stated to be more looking for internal and external linkages and social relationship to benefit the organization. Therefore, ambidextrous employees could be more likely to think in the best interest of the organization they work for, instead of mainly pursuing their own interest (Gibson \& Birkinshaw, 2004).

Result shows that exploration and goal focus are positively related. As mentioned earlier, there exist no empirical evidence on the relationship between exploration and goal focus. Notwithstanding, this result is similar to the study by Auh and Mengue (2005) who reported a significant relationship between organizational Ambidexterity and firms Growth. Drawing from our earlier argument that organizations cannot grow if they are not healthy, we therefore insist that firm's growth is synonymous to firm's health status. The significance of this result lies in the fact that organizations that want to maintain a healthy status must be goal focused, that is they must possess the ability to have clarity, acceptance, support, and advocacy of school wide goals as well as objectives. An organization that wants to achieve a sound health 
status through ambidexterity should attain high levels of cooperation internally and externally, for cooperation will create new and shared knowledge which will enhance the exploration and exploitation activities of the organization which in turn predicts corporate health. This is in line with earlier research, showing that knowledge transfer is important for innovative activities which will cause organizations to be healthy (Carlile, 2004; Jansen, Tempelaar, Bosch, \&Volberda, 2009; Kauppila, 2010).

\section{Recommendations}

In view of the conclusion drawn above, this study therefore presents the following recommendations:

(i) Since exploratory activities enhance resource utilization, managers should acknowledge the importance of exploration in fostering a better resource utilization which will bring about a healthy organization. Employee involvement, especially employees that are opened to change should be encouraged at all level of the organization.

(ii) Conscious effort should be made to sensitize employees at all levels to embrace exploratory activities as it is initiated by top management. Exploring existing competencies demands among others full cooperation of employees, their effort in pursuing exploration is needed from time to time as the organization moves towards achieving its strategic objectives.

(iii) Management should give full support to exploitative activities within the organization since exploitation enhances resource utilization. Partnering up with competitors, customers, as well as suppliers is very important. There should be sound and robust communication channels as these will foster healthy relationship among organizational members as well as accentuate the importance of cooperation across organizational boundaries as a way of hasting the process of a healthy organization. 


\section{Bibliography}

Abernathy, W. J. - Clark, K. B. (1985): Innovation: Mapping the winds of creative destruction. Research Policy, (14): p. 3-22.

Abernathy, W.J., K. Clark 1985, Mapping the Winds of Creative Destruction. Research Policy 14 3-22.

Adelowo, W. B. (2018). Labour commitment and firm's productivity in Nigeria: A case study of Global Soap and Detergent Industries Limited, Ilorin, Kwara State. IOSR Journal of Agriculture and Veterinary Science (IOSR-JAVS), 7(5), 1-8.

Adler P.S, Goldoftas B., and Levine (1999).Flexibility vs. Efficiency?A case study of model changeovers in the Toyota production system. Organization Science. 10: 43-68.

Ahuja, G. - Lampert, C. (2001): Entrepreneurship in the large corporation: A longitudinal study of how established firms create breakthrough inventions. Strategic Management Journal, (22): p. 521-543.

Ahuja, G. \&Katila.K. (2004). Where do resources come from? The role of Idiosyncratic situations, strategic management journal, 25, 887-543.

Ahuja, G. and Lampert, C.M. 2001. Entrepreneurship in the Large Corporation: A Longitudinal Study of how established firms create breakthrough inventions. Strategic Management Journal, 22: 521-543.

Akgun, A. E., Lynn, G. S., \& Byrne, J. C. (2003). Organizational learning: A socio cognitive framework. Human Relations, 56(7), 839-868.

Amin, S. (1999).Young women's experiences in the labor market in developing countries. Conference on Labor Market and Human Resource Development in Egypt, Economic Policy Initiative Consortium (EPIC) and Center for the Study of Developing Countries, Faculty of Economics and political Science, Cairo University, Cairo.

Anand, J., Mesquita, L. F., \&Vassolo, R. S. (2019).The dynamics of multimarket competition in exploration and exploitation activities. Academy of Management Journal, 52(4), 802-821.

Ancona, D. G. - Goodman, P. S. - Lawrence, B. S. - Tushman, M. L. (2001): Time: A new research lens. Academy of Management Review, (26): p. 645-663.

Andriopoulos, C., \& Lewis, M. W. (2009).Exploitation-exploration tensions and organizational ambidexterity: Managing paradoxes of innovation. Organization Science, 20(4), 696-717.

Argote, L. (1999). Organizational learning.New York: Springer.

Argyris, C. - Schön, D. (1978): Organizational learning: A theory of action perspective. Reading, MA: Addison- Wesley.

Arppe, A. (2008). Bivariate, bivariate and multivariate methods in corpus-based lexicography.A study of synonymy. Helsinki: University of Helsinki. 
AtuaheneGima, K. (2017). Resolving the capability rigidity paradox in new product innovation. Journal of Marketing, 69(4), 61-83.

Baayen, R. H. (2014). Multivariate statistics. Canada: University of Alberta, Edmonton.

Bagozzi, R. P. \& Yi, Y. (1988).On the evaluation of structural equations models.Journal of Academy of Marketing Science, 16(1), 74-94.

Bakka, J.F., Fivelsdal, E., \&Lindkvist, L. (2001) Organisational structure, culture, processer.(4th ed.) Malmö; Liber Ekonomi.

Balu, P.M and Schoenherr, R.A (1980) The Structure of Organisations. Basics Books, New York.

Baruch, Y. \&Holtom, B. C. (2008).Survey response rate levels and trends in organizational research.Human Relations, 61(8), 1139-1160.

Bazeley, P. (2009). Analysing qualitative data: More than 'identifying themes'.Malaysian J. Qualitative Res., 2, 6-22.

Benner, M. J. and Tushman, M. L. (2003), Exploitation, Exploration, and Process Management: The Productivity Dilemma Revisited, Academy of Management Review, 28 , pp. 238-256.

Benner, M. J., \&Tushman, M. L. (2002). Process management and technological innovation: A longitudinal study of the photography and paint industries. Administrative Science Quarterly, 47(4), 676-706.

Birkinshaw, J. \& Gupta, K. (2018): Clarifying the Distinctive Contribution of Ambidexterity to the Field of Organization Studies. Academy of Management Perspectives, 27(4): p. 287-298.

Birkinshaw, J. and Gibson, C. (2004), Building Ambidexterity into an Organization, MIT Sloan Management Review, 45, pp. 46-55.

Birkinshaw, J. and Gibson, C. (2004b), Building an Ambidextrous Organization, Aim Research Working Paper Series, 003, pp. 1-18.

Blackburn, R. \& Cummings, L. L. (1982).Cognitions of work unit structure. Academy of Management Journal, 25, 836-854.

Brown, J. S., \&Duguid, P. (1991). Organizational learning and communities of practice: Toward a unified view of working, learning, and innovation. Organization Science, 2(1), 40-57.

Buluc, B. (2008). The Relationship Between Organizational Health and Organizational Citizenship Behaviors in Secondary Schools. Turkish Educational Sciances Journal, 6(4), 571.

Burns, L. R., D. R. Wholey. (1993). Adoption and abandonment of matrix management programs: Effects of organizational Characteristics and interorganizational networks. Academy of Management Journal. 36(1) 106-138. 
Burton, M. Diane, O’Reilly, Charles A. and Bidwell Matthew. Management systems for exploration and exploitation: The micro-foundations of organizational ambidexterity. Paper presented at the annual meetings of the Academy of Management, Boston, August, 2012.

Canova, S., Cortinovis, D. L. \&Ambrogi, F. (2017).How to describe bivariatedata.Journal of Thoracic Disease, 9(6), 1741-1743.

Cao, Q., Gedajlovic, E., \& Zhang, H. (2019). Unpacking organizational ambidexterity: Dimensions, contingencies, andsynergisticeffects.OrganizationScience, 20(4), 781796.

Caspin-wagner, keren, Ellis, Shmuel and tishler, Asher. 2012. Balancing exploration and exploitation for firm's superior performance: the role of the environment. Paper presented at the annual meetings of the Academy of management.

Chandrasekaran, A., Linderman, K., \& Schroeder, R. (2012)."Antecedents to ambidexterity competency in high technology organizations". Journal of operations management, vol. 30, issue $1 / 2$, pp. 134-151.

Chermack, T. J., (2007). Disciplined imagination: Building scenarios and building theories. Futures, 39(1), 1-15.

Christophe, J. N. \& François-Charles, W. (2009).Gender differences in pay in African manufacturing firms. HAL, Working Paper No. 00421227.

Clark-Carter, D. (2010). Quantitative psychological research: the complete student's companion ( $3^{\text {rd }}$ ed.). Hove: Psychology Press.

Cohen, W. M., \&Levinthal, D. A. (1989). Innovation and learning: The two faces of R \& D. The Economic Journal, 99(397), 569-596.

Cooper (1994). “The Cost of Healthy Work Organizations” in C. L. Cooper and S. Williams. Creating Healthy Work Organizations, chichester, John Wiley.

Cronbach, L. J. \&Meehl, P. E. (1955). Construct validity in psychological tests. Psychological Bulletin, 52(4), 281-302.

Crossan M. M. and Apaydin, M. (2010). A multi-dimensional framework of organizational innovation: A systematic review of the literature, Journal of Management Studies, 47 (6): 1154-1191.

Crossan, M. M., Lane, H. W., \& White, R. E. (1999). An organizational learning framework: From intuition to institution. Academy of Management Review 24(2), 522-537.

Crossan, M., Vera, D., and Nanjad, L. (2008).Transcedent Leadership: Strategic Leadership in Dynamic Environments. Leadership Quaterly, 19: 569-581.

Damanpour, F. 1991. Organizational innovation: A metal- analysis of effects of determinants and moderators. Academy of management Journal, 34: 555-590.

Danneels, E. 2002.The dynamics of product innovation and firm competences. Strategic Management Journal, 23, 1095-1121. 
Dixon, N. M. (1992). Organizational learning: A review of the literature with implications for HRD professionals. Human Resource Development Quarterly, 3(1), 29-49.

Doz, Yves, Christopher Barlett, and C. K. Prahalad (1981). "Global Competitive Pressures And Host Country Demands: Managing Tensions in Multinational Corporations," California Management Review 23 (3): 63-74.

Drazin R and Van de Ven AH (1985). Alternative forms of fit in contingency theory. Administrative Science Quarterly, 30.

Drew, W. \& Robert, R. (2003). Quantifying construct validity: Two simple measures. Journal of Personality and Social Psychology, 84(3), 608-618.

Easterby Smith, M. (1997). Disciplines of organizational learning: contributions and critiques. Human Relations, 50(9), 1085-1113.

Ebben, J. J., \&Johnson, A. C. 2005.Efficiency, flexibility, or both?Evidence linking strategy to performance in small firms. Strategic Management Journal, 26, 1249-1259.

Eccles, RG and Crane DB (1988) Doing Deals: Investment banks at work. Harvard Business School Press, Boston.

Eisenhardt, K. M., \& Brown, S. L. (1998).Competing on the edge: Strategy as structured chaos. Long Range Planning, 31(5), 786-789.

Eisenhardt, K. M., \& Martin, J. A. (2000). Dynamic capabilities: What are they? Strategic Management Journal, 21 (10-11), 1105-1121.

Ettlie, J. E., Bridges, W. P., \& O’Keefe, R. D. (1984). Organization strategy and structural differences for radical versus incremental innovation. Management Science, 30(6), 682-695. doi: 10.1287/mnsc.30.6.682

Fincham, J. E. (2008). Response rates and responsiveness for surveys, standards, and the journal.American Journal of Pharmaceutical Education, 72 (2), 1-3.

Fornell, C. \&Larcker, D. G. (1981).Evaluating structural equation models with unobservable variables and measurement error.Journal of Marketing Research, 18(1), 39-50.

Geerts, A. Blindenbach-Driessen and F. Gemmel 2010.Achieving a balance between exploration and exploitation in service firms.A longitudinal study. Academy of management proceedings 2010(1): 1-6. Google scholar, crossref.

Ghemawat, P. - Ricarti Costa, J. (1993): The organizational tension between static and dynamic efficiency. Strategic Management Journal, (14): p. 59-73. Duncan, R. B. (1976): The ambidextrous organization: Designing dual structures for innovation. in: R. H. Kilmann - L.R. Pondy - D. Slevin (eds.): The management of organization design: Strategies and implementation. New York: North Holland: p. 167-188.

Ghoshal S and Nohria N (1989) internal differentiation within multinational corporations. Strategic Management Journal, 10. 
Gibson DG, et al. (2004). Diminished S-Phase cyclin-dependent kinase functions elicits vital Rad53-dependent checkpoint responses in saccharomyces cerevisiae. Moll Cell Biol 24(23):10208-22

Gibson, C. B. and Birkinshaw, J. (2004), The Antecedents, Consequences, and Mediating Role of Organizational Ambidexterity, Academy of Management Journal, 47, pp. 209-226.

Gibson, J. L. \& Klein, S. M. (1970). Employee attitudes as a function of age and length of service: A reconceptualization. The Academy of Management Journal, 13(4), 411425.

Goosen, M. C., Bazzazian, N., \& Phelps, C. (2012). Consistently capricious: The performance effects of simultaneous and sequential ambidexterity. Paper presented at the annual meetings of the Academy of Management.

Goosen, Martin C., Bazzazian, Navid and Phelps, Corey (2012).Consistently capricious. The performance effects of simultaneous and sequential ambidexterity. Paper presented at the annual meetings of the Academy of Management.

Grant, R. M. (1996). Prospering in Dynamically-competitive Environments: Organizational Capability as Knowledge Integration. Organizational Science, 7(4), 375-387.

Gravetter, F. J., \&Wallnau, L. B. (2000).Statistics for the behavioral sciences $\left(5^{\text {th }}\right.$ edn).Belmont, CA: Wadsworth.

Greve, H. R. (2007). Exploration and exploitation in product innovation. Industrial and Corporate Change, 16(5), 945-975. doi: 10.1093/icc/dtm013

Gupta, A. K. - Smith, K. G. - Shalley, C. E. (2006): The interplay between exploration and exploitation. Academy of Management Journal, 49(4): p. 693-706.

Hair, J. F., Jr., Anderson, R. E., Tatham, R. L. \& Black, W. C. (1998). Multivariate data analysis $\left(5^{\text {th }}\right.$ ed). Englewood Cliffs, NJ: Prentice Hall.

Han, M. and Celly, N. (2008), Strategic Ambidexterity and Performance in International New Ventures, Canadian Journal of Administrative Sciences, 25, pp. 335-349.

Hatch M. J., (1993). "The dynamics of organizational culture". Academic Of Management Review, Vol. 18, pp. 657-93.

Hatch, M. J. (1997). Organization Theory: Modern Symbolic and Postmodern Perspectives. New York: Oxford University Press Inc.

Hatch, M.J., \&Cunliffe, A.L. (2006).Organisation Theory modern, symbolic and postmodern perspective.Oxford University Press; New York.

He, Z. L. and Wong, P. K. (2004), Exploration vs. Exploitation: An Empirical Test of the Ambidexterity Hypothesis, Organization Science, 15, pp. 481-494.

Hernandez-Esparllardo, M., Sanchez-Perez, M., and Segovia-Lopez.C. (2011). Exploitationand- Exploration-based-innovation: The role of knowledge in inter-firms relationships with distributions. Technovations, 31(5-6), 203-215. 
Holmqvist, M. (2009). Comparing the organization: A new prescription for the learning organization? Management Learning, 40(3), 275-287.

Hoy, W. K., \&Fieldman, J. A., (1987). Organizational Health: The Concept and its measure. Journal of Research and Development in Education, 20, 20-38.

Huber, G. (1991). Organizational learning: the contributing processes and the literatures. Organization Science, (2)1, 88-115.

Huber, G. P., \& Lewis, K. (2010). Cross understanding: Implications for group cognition and performance. Academy of Management Review, 35(1), 6-26.

Ireland, R. D., Hitt, M. A., \&Sirmon, D. G. (2003). A model of Strategic Entrepreneurship: The construct and its dimensions. Journal of Management, 29: 963-989.

Jansen, J. (2005), Ambidextrous Organizations: A Multiple-Level Study of Absorptive Capacity, Exploratory and Exploitative Innovation and Performance, Unpublished Dissertation, ERIM https:// ep.eur.n1/handle/1765/6774 .

Jansen, J. J. P., Van den Bosch, F. A. J. and Volberda, H. W. (2005), Exploratory Innovation, Exploitative Innovation, and Ambidexterity: The Impact of Environmental and Organizational Antecedents, Schmalenbach Business Review, 57, pp. 351-363.

Jansen, J.J., Vanden Bosch, F.A., \& Volberda, H.W.(2006). Exploratory innovation, exploitative innovation, and performance: Effects of organizational antecedents and environmental moderators. Management Science, 52(11), 1661-1674.

Joe Tidd and Kuo-Nan Hsieh (2013). Open Service Innovation: The influences of Projects Novelty. Open Innovation Research Management and Practice: pp.159-185.

Junni, P., Sarala M. Rikka, Taras, Vas and Tarba, ShlomoYedida. (2013). Organizational ambidexterity and performance: A meta-analysis. Academy of Management Perspectives, 27(4) 299-312.

Karaguzel O.T., Zhang R., \& Liam K. P (2018). "Integrated Simulation Based Design Optimization of Office Building Envelopes for the Minimization of Life Cycle Cost". The Second International Conference on Building Energy and Environment(COBEE 2012). Boulder, CO, U.S. August, 2012.

Katila, R., \&Ahuja, G. (2002). Something old, something new: A longitudinal study of search behavior and new product introduction. Academy of Management Journal, 45.

Langan-Fox, J., Anglim, J., \& Wilson, J. R. (2004). Mental models, team mental models, and performance: Process, development, and future directions. Human Factors and Ergonomics in Manufacturing, 14(4), 331-352.

Laplume, A. O. - Dass, P. (2012): Exploration and exploitation for various stages of firm growth through diversification. Paper presented at the annual meetings of the Academy of Management, Boston, August 
Lawrence P.R and Lorsch J.W (1967) 'Organisation and Environment: Managing Differentiation and Integration ', Boston, Division of Research, Graduate School of Business Administration, Harvard University.

Levinthal, D. - March, J. (1993): Myopia of learning. Strategic Management Journal, (14): p. 95-112.

Li, Y., Vanhaverbeke, W., \&Schoenmakers, W. (2008). Exploration and exploitation in innovation: reframing the interpretation. Creativity and Innovation Management, 17(2), 107-126. doi: 10.1111/j.1467-8691.2008.00477.x

Liao, T. F. 2004. Comparing social groups: Wald statistics for testing equality among multiple logit models. International Journal of comparative sociology, 45: 3-16.

Lorsch, J. W. (1976). Contingency theory and organization design: A personal odyssey. In: R. H Kilmann, L. R. Pondy, \& D. P. Slevin (Eds.), The management of organization design,(pp. 141-169). New York: Elsevier North-Holland, Inc.

Lovas, B and Ghoshal, S. (2000). Strategy as Guided Evolution.Strategic Management Journal, 21, 875-96.

Lubatkin, M. H., Pimpek, Z., Ling, Y. and Veiga, J. F. (2006), Ambidexterity and Performance in Small- to Medium-Sized Firms: The Pivotal Role of Top Management Team Behavioral Integration, Journal of Management, 32, pp. 646-672.

Lumpkin, G. T., \&Dess G. G. (1996). Clarifying the entrepreneurial orientation construct and linking it to performance. Acedemy of Management Review, 21(1), 135-172.

March, G. James, (1991), Exploration and Exploitation in Organizational Learning, Organization Science, 2,pp.78-87.

Markides, C, and charitou, C. D. (2004).competing with dual business models: a contingency approach. Academy of management Executive, 18: 22-36.

Marquardt, M. J. (1999). Action learning in action: Transforming problems and people for world-class organizational learning. Palo Alto, CA: Davies-Black Publishing.

McGrath, R. 2001. Exploratory learning, innovative capacity, and managerial oversight.Academy of Management Journal, 44, 118-1.

Mclver, J. P., \& Carmines, E. G.(1981). Unidimensional scaling. Thousand Oaks, CA: Sage.

Mehrabi, J., Gharakhani, D., Jalalifar, S., \&Rahmati, H. (2012).Barriers to Green Supply Chain management in the petrochemical sector.Life Science Journal, 9(4), 3438-3442.

Miles, M. B. (1969). Planned change and organizational health: Figure and ground. In F.D. Carver \& T.J. Sergiovanni(Eds), Organizations and Human Behavior (pp. 375-391). New York McGraw Hill.

Mintzberg, H. (1983). Designing effective Organisations.Prentice Hall, Inc. New Jersey.

Mintzberg, H. (1983). Power in and around organization. Englewood Cliffs, NJ: PrenticeHall. 
Mukalula, PM (1996) Structural adjustment for a competitive environment: Survival strategies for medium sized organisation firms in Zambia .International Symposium for the Organisation and Management of Organisation, Spon, London.

Narver, J. C. \& Slater, S. F. (1995).“Market Orientation and Learning Organization”. Journal of Marketing, 59 (3): 63-74.

Nelson R.R. \& Winter S.G. (1982). The Schumpeterian Tradeoff Revisited. The American Economic'

Niazi, M. \&Yazdekhasti, A. (2010).Organizational Health, Sokhanvaran Publishers $1^{\text {st }}$ impression.

Nordman, C. J. \& Wolff, F. C. (2018).Gender differences in pay in African manufacturing firms. In: Gender disparities in Africa's labor market. Washington, D.C, United States. World Bank, Pp. 155-191.

O'Reilly, C. A. - Tushman, M. L. (2004): The ambidextrous organization. Harvard Business Review, (82): p. 74-81.

O'Reilly, C. A. - Tushman, M. L. (2013): Organizational Ambidexterity: Past, Present, and Future. The Academy of Management Perspectives, 27(4): p. 324-338.

Pisano, G. P. (1994). Knowledge integration and the locus of learning: An empirical analysis of process development.

Polit, D. F. \& Beck, C. T. (2012).Nursing research: Generating and assessing evidence for nursing practice $\left(9^{\text {th }}\right.$ ed.). Philadelphia, USA: WoltersKlower Health, Lippincott Williams \& Wilkins.

Porter, M. E. (1980). Competitive strategy: Techniques for analyzing industries and competitors. New York: Free Press.

Porter, M. E. 1996. Wettbewerbsvorteile: spitzenleistungenerreichenundbehaupten. Frankfurt: campus.

Ppoadiuk, S. \&choo C. W. (2006). Innovation \& knowledge creation: How are these concepts related? International journal of information management, 26 (4), 302-312.

Prahalad,C.K.,\&Hamel,G.1990.Thecorecompetencies thecorporation.HarvardBusinessReview,68(3): 79-90.

Prieto, I. M. Revilla, E. \& Rodriguez-prado, B. (2009).Managing the knowledge paradox in product development.Journal of knowledge management, 13, 147-45.

Raisch, S. and Birkinshaw, J. (2008), Organizational Ambidexterity: Antecedents, Outcomes, and Moderators, Journal of Management, 34, pp. 375-409.

Raisch, Sebastian, Birkinshaw, Julian, Probst, Gilbert and Tushman, Micheal L. (2009). Organizational ambidexterity: Balancing exploitation and exploration for sustained performance. Organization Science, 20: 685-695. 
Raish, S. (2008).Balanced Structures: Designing organizations for profitable growth.Long Range planning 41(5) 483-508.

Robbins S. P. (1990), Organization theory, Englewoods Cliffs, Prentice Hall.

Rotemberg, J. J. \& G. Saloner (2000)."Visionaries, Managers, and Strategic Direction", RAND Journal of Economics 31: 693-716.

Rotemberg, J. J. And Saloner, G. "Leadership Style and Incentives".Management Science Vol. 39(1993), pp. 1299-1318.

Rumsey. D. J. (2019). How to Interpret a Scatterplot.https://www.dummies.com/education/math/statistics/how-to-interpret-ascatterplot/

Sekaran, U. (2003). Research methods for business $\left(4^{\text {th }}\right.$ ed.). Hoboken, NJ: John $\quad$ Wiley $\quad \&$ Sons.

Shapiro, S. L., Schwartz, G. E., \& Bonner G. (1998). Effects of mindfulness-based stress reduction on medical and premedical students. Journal of Behavioral Medicine, 21: 581-599

Sidhu JS, Volberda HW, Commandeur HR. 2004. Exploring Exploration Orientation and Its Determinants: Some Empirical Evidence. Journal of Management Studies 41(6): $913-$ 932

Siren, C. A., Kohtamaki, M., \&Kuckertz, A. (2012). Exploration and Exploitation Strategies, Profit Performance, and the Mediating role of strategic learning: Escaping the Exploitation of trap. Strategic Entrepreneurship Journal, 6(1), 18-41.

Sitkin, S. B., \& Pablo, A. L., (1992).Reconceptualizing the determinants of risk behavior. Academy of Management Review, 17(1), 9-38.

Slater, S. F., \&Narver, J. C. (1995).Market orientation and the learning organization. Journal of Marketing, 59(3), 63-74. doi: 10.2307/1252120.

Smith, W. - Tushman, M. L. (2005): Managing strategic contradictions: A top management model for managing innovation streams. Organization Science, 16(5): p. 522-536.

Sossay, C. A., Hyland, P. W. \&Ferrer, M. (2008). Supply chain collaboration: Capabilities for continuous innovation. Supply chain management-an international journal, 13(2), pp. 160-169.

Sunkuk K (1997) Organisation and managerial environment of the Korean organisation', Organisation Management and Economics, 15, 409-419.

Szulanski, G. (2003). Sticky knowledge.Barriers to knowing in the firm. Thousand Oaks, CA: Sage.

Tavakol, M., \&Dennick, R. (2011). Making sense of Cronbach's alpha. International Journal of Medical Education, 2, 53-55. 
Taylor, Alva HelfatCostance E. (2009). Organizational linkages for surviving technological change: Complementary assets, middle management and ambidexterity. Organization Science, 20: 718-739.

Teece, D. J., Pisano, G., \&Shuen, A. (1997). Dynamic capabilities and strategic management. Strategic Management Journal, 18(7), 509-533).

Tempelaar, M. P., \& Van De Vrande, V. (2012).Dynamism, munificence, internal and external exploration-exploitation and their performance effects. Paper presented at the annual meetings of the academy of management.

Tidd, J. and J. Bessant (2013). Managing Innovation: Integrating technological, market and organizational change. Chichester, john Wiley and Sons.

Tran and Tidd (2013).Effects of Organizational Structures and Learning Organization on Job Embeddedness and Individual Adaptive Performance.

Tran T (2008). A conceptual model of learning culture and innovation schema. Int. Bus. J., 18(3): 287-299.

Tushman, M. L. and O'Reilly, C. A. (1996), Ambidextrous Organizations: Managing Evolutionary and Revolutionary Change, California Management Review, 38, pp. 830.

Tushman, M., Smith, W. K., Wood, R. C., Westerman, G., \& O’Reilly, C. (2010).Organizational designs and innovation streams. Industrial and Corporate Change, 19(5), 1331-1366. doi: 10.1093/icc/dtq040.

Tushman, Micheal L. and O'Reilly, Charles A. (1996). The ambidextrous organizations: Managing evolutionary and revolutionary change. California Management Review, 38: $1-23$.

Tutar, H. \&Yilmaz, K. M. (2010).Geneliletisimkavramlarvemodellar [General Communication concepts and Models]. Ankara: Seckin Yayincilik.

Uotila, J., Maula, M., Keil, T., \& Zahra, S. A. (2009).Exploration, exploitation, and financial performance: Analysis of S\&P 500 corporations. Strategic Management Journal, 30(2), 221-231.

Uotila, Juha, Maula, Markku and Keil, Thomas and Zhara, Shaker A. 2008. Exploration, exploitation and firm performance: An analysis of S\&P 500 corporations. Strategic Management Journal, 30: 221-231.

Venkatraman V, Payne JW, Bettman JR, Luce MF, Huettal SA. Separate neural mechanisms underlie choices and strategic preferences in risky decision making. Neuron 2009; 62: 593-602. (PMC free article) (PubMed)

Voss, G. B. Sirdeshmukh, D. \&Voss, Z. G. (2008), the effects of slack resources and environmental threat on product exploration and exploitation. Academy of management journal, 51, 147-164. 
Wang, Q., \& von Tunzelmann, N. (2000). Complexity and the functions of the firm: Breadth and depth. Research Policy, 29(7-8), 805-818.

Weick, K. E. (1991). The nontraditional quality of organizational learning. Organization Science, 2(1), 116-124.

West MA, Borrill CS, Dawson JF, Scully J, Carter M, Anelay S, Patterson MG, Waring J. (2002).'The link between the management of employees and patient mortality in acute hospitals'. International Journal of Human Resource Management, vol. 13, pp 12991310.

West, M. A., and Farr, J. L., (1990).Innovation at work.In M. A. West and J. L. Farr (Eds.). Innovation and creativity at work (pp. 03-13) New York: John Wiley and sons.

Winter, S.G.(2003).Understanding dynamic capabilities. Strategic Management Journal, 24(10), 991-995.

Yu, G.J. \& O. M. Khessina.(2012). "The role of Exploration in Firm survival in the Worldwide Optical Library Market, 1983-1999." Presented at 2012 Meeting of Academy of Management Meeting, Technology and Innovation Division, August, Boston, MA.

Zhang Y. et al. (2007). The role of autophagy in mitochondria maintenance: Characterization of mitochondrial functions in autophagy-deficient S. cerevisiae strains. Autophagy 3(4):337-46.

Zikmund, W. G., Babin, B. J., Carr, J. C. \& Griffin, M. (2010).Business research methods $\left(8^{\text {th }}\right.$ ed.). Mason, HO: Cengage Learning. 